\title{
The grass-free lawn: floral performance and management implications
}

Article

Accepted Version

Creative Commons: Attribution-Noncommercial-No Derivative Works 4.0

Smith, L. S. and Fellowes, M. D. E. (2015) The grass-free lawn: floral performance and management implications. Urban Forestry \& Urban Greening, 14 (3). pp. 490-499. ISSN 16188667 doi: https://doi.org/10.1016/j.ufug.2015.04.010 Available at https://centaur.reading.ac.uk/45984/

It is advisable to refer to the publisher's version if you intend to cite from the work. See Guidance on citing.

Published version at: http://dx.doi.org/10.1016/j.ufug.2015.04.010

To link to this article DOI: http://dx.doi.org/10.1016/j.ufug.2015.04.010

Publisher: Elsevier

All outputs in CentAUR are protected by Intellectual Property Rights law, including copyright law. Copyright and IPR is retained by the creators or other copyright holders. Terms and conditions for use of this material are defined in the End User Agreement.

\section{www.reading.ac.uk/centaur}

\section{CentAUR}

Central Archive at the University of Reading

Reading's research outputs online 


\section{The grass-free lawn: floral performance 2 and management implications.}

3

4 Lionel S Smith \& Mark D E Fellowes

5

6 School of Biological Sciences, University of Reading, Whiteknights, 7 Reading RG6 6AS, UK 8 
10 Abstract

11 Grass lawns are a ubiquitous feature of urban green-space throughout much of the temperate world.

12 Species poor and intensively managed, lawns are ecologically impoverished, however environmentally aware lawn owners are reluctant to implement alternatives due to aesthetic concerns.

14 Developing an alternative lawn format which is both biodiversity friendly and aesthetically pleasing is 15 an imperative for urban greening.

16 We suggest that such an alternative can be provided by replacing the grass lawn by a forb-based mix.

17 To advance this, we tested the floral performance of three groups of clonal perennial forbs (native,

18 non-native and mixed), each maintained using standard lawn management mowing regimes.

19 Our findings show that both the frequency of mowing and the height at which mowing is applied influence floral performance and lawn aesthetics. Species origin was found to influence floral productivity, floral visibility and floral variety within grass-free lawns, with native species providing the greatest floral performance. The behaviour and management of grass lawns was not found to be a suitable analogue for the management of grass-free lawns and grass-free lawns are sufficiently different from grass lawns to require an entirely original management approach. We suggest that the grass-free lawn can provide an aesthetically and environmentally relevant replacement for the ubiquitous and ecologically-poor grass lawn. 
Originally composed of a mixture wild grasses and mowing tolerant wildflowers native to the relatively moist and mild maritime climate of NW Europe, the pedigree of the lawn can be traced back nearly a thousand years (Fort, 2000;Smith and Fellowes, 2013). During this time continuous social and economic changes combined with greater general access to improving horticultural technology have seen the ornamental lawn extend its original range, moving from private country estates and parks and into the urban landscape (Macinnis, 2009). This journey transformed the lawn. Although a climatically suited mixture of grasses and forbs is still commonly found throughout lawns in NW Europe (Fogelfors, 1983;Müller, 1990;Godefroid, 2001; Thompson et al., 2004), horticultural and aesthetic refinements have been applied to it. The aesthetically refined lawn has taken on very particular characteristics that separate it from its original mixed species composition. The refined or 'perfect' lawn is a low, evenly planed, grass-only format that is required to be a rich green monotone in colour without mottling or spoil that should be dense and soft of texture (Steinberg, 2007;Slater, 2007). Only very few grass species can meet these requirements and the perfect lawn is inevitably a species poor monoculture. However this refined composition has produced an aesthetic that is much admired; so much so that it has been widely adopted beyond its point of origin and the lawn is now the most common component of urban greenspace worldwide (Stewart et al., 2009;Ignatieva and Stewart, 2009).

Even though it is widely implemented, the monocultural nature of the perfect lawn is not without its critics (Robbins, 2007). Changing perceptions of the urban environment and a new green zeitgeist in gardening now see eco-friendly characteristics, native plants, wildlife and sustainability being included in decisions made by landscapers and gardeners (Helfand et al., 2006;Clayton, 2007;Gaston et al., 2007;Kiesling, 2010). This has led to lawns and their management being seen as ecologically insensitive, with refined lawns being perceived as 
'green deserts'(Allen et al., 2010), and described as 'industrial lawns' due to the high level of inputs required to maintain the refined aesthetic (Borman et al., 2001).

Intensively maintaining greenspace to be species poor does not fit comfortably within the trend for greener gardening and alternatives to the refined lawn format are suggested by many garden authors, gardening organisations and local authorities (Marinelli, 1993;Daniels, 1995;Ryall and Hatherell, 2003;Thomas, 2010;Anon, 2011a;Brown, 2011). Alternatives can include lawns composed of regionally indigenous grasses (Simmons et al., 2011), species enriched lawns (Cook, 1993) and single forb species replacements (Smith and Fellowes, 2013), but more commonly the suggestion is for the lawn to be replaced entirely, usually with a variety of herbs, shrubs and trees, (Hadden, 2012), often with the condition of being native seen as a positive feature in replacement species choices (McMahan, 2006).

However where the use of lawn alternatives has been investigated (primarily in North America), alternatives are not found to be widely adopted, and there is little correlation between a lawn owners choice of alternatives and their environmental motivations (Henderson, 1998;Feagan, 2001); alternatives tend to be implemented on the basis of aesthetic improvement (Purchase, 1997). This is in large part due to cultural norms found in North America where the lawn has particular symbolic value (Feagan and Ripmeester, 1999; Robbins, 2003;Steinberg, 2007), but is also indicative of the social dimensions in urban ecology (Pickett et al., 2001) and the role of aesthetics in lawn space management (Byrne, 2005;Piekielek, 2003). For a lawn alternative to sit comfortably within the green paradigm and be socially agreeable it would require both an ecological motivation, be aesthetically relevant and socially acceptable (Nassauer et al., 2009).

A new alternative approach to lawns that retains many of the traditional lawn features but removes both the grass and the monoculture has been trialled at the University of Reading, 
Berkshire, UK. By showing human intention through careful species selection, retaining the traditional low visual aspect and neatness of a lawn by the application of mowing, and providing a level of cover equivalent to that found in traditional grass lawns, the grass-free lawn keeps some of the key characteristics of the ornamental lawn template, although the requirement for mowing is significantly reduced (Smith and Fellowes, 2014a). Composed of mowing tolerant clonal perennial forbs, the grass-free lawn has greater plant species diversity at inception and by the use of a mixture of species that all have the capacity to produce flowers, grass-free lawns bring floral performance to a space not traditionally managed for flowers. Although not intended for sport or amenity use the increase in plant diversity and floral resource found in a grass-free lawn may fit better within the green zeitgeist than the use of the traditional monoculture, and also be aesthetically pleasing; a feature that has the potential to positively influence its societal acceptability (Nassauer, 1995).

With the exception of its initial and subsequent annual or biannual application in wildflower meadows and prairie (Jefferson, 2007;Wade, 2012), the use of repeated mowing is not traditionally associated with floral management. The influence that different types of mowing regimes and plant species selection will have on the floral performance of grass-free lawns has yet to be reported on. In a preceding paper we identified that mowing can influence the amount of ground cover and plant species survival in grass-free lawns (Smith and Fellowes, 2014a), this has implications for the application of mowing to grass-free lawns for the purposes of floral display. For a grass-free lawn to be maintained as a lawn rather than a low meadow it must be mown more frequently. Mowing will inevitably influence floral visibility by the repeated removal of flowers, and the height at which the cut is applied and interactions between the plants used are also likely to influence the outcome. A mowing regime that 
results in the greatest level of plant and floral diversity and visual performance can be considered to be the optimum management approach.

To determine this approach while we examined the influence of three mowing regimes on ground coverage and species survival in native, non-native, mixed species and turf lawns, we concurrently examined the biomass production and floral performance. Biomass was recorded to compare the productivity of grass-free lawns with unrefined grass lawns under the different mowing regimes and to identify any biomass related behaviour in the floral performance of the lawns.

\section{METHOD}

\section{Experimental Design}

As described in greater detail in our preceding paper (Smith and Fellowes, 2014a), three groups of clonal perennial forbs were created from species deemed likely to survive and reproduce in a mown environment; a native species group, a non-native group and a mixed species group. The native group was composed in equal proportions of ten species commonly found in managed grasslands and lawns throughout the UK. The non-native group contained ten species of non-natives also in equal proportion that had been sourced on the basis of commercial availability (Table 1). The mixed group consisted of all the native and non-native species in equal proportion. All species selected had the potential to produce clearly visible, distinct and colourful flowers. For the purposes of comparison grass lawn plots were sourced from a section of the university's lawn that was known not to have received any lawn management treatments beyond regular mowing for a period of over twenty years.

The layout of the experiment consisted of thirty six $60 \mathrm{~cm}^{2}$ randomised grass-free plots and twelve grass lawn plots. Each grass-free plot contained one hundred plants that had been 
either propagated via cuttings or from seed where cuttings were impractical. Visual examples of all groups cut at 4cm in May 2011 are shown in Fig 1.

Three mowing treatments were applied to designated plots continuously over two years from April 2011. The period of mowing the lawns was bound by the start and end of the growing season in both years. Treatments were either a) a monthly cut where plots were cut down to $4 \mathrm{~cm}$ on the same date of each month (weather depending) irrespective of plant height meter of 5g (Barnhart, 1998;Rayburn, 2003). height, only flowers that were clearly and individually distinguishable at this height were 
clearly distinguished in this manner were those of Stellaria graminea, with flowers of approximately $5 \mathrm{~mm}$ diameter and all flowers were therefore individually countable.

When counting flower number a floral cluster composed of many small individual flowers smaller than $5 \mathrm{~mm}$ was recorded as a single flower rather than as many individual tiny flowers; larger visibly discrete flowers of $5 \mathrm{~mm}$ and over were individually counted.

Floral visibility. Perception of how flower filled a space appears to be is influenced by both the number and the size of the flowers observed within that space. When compared directly, a few large flowers are seen to inhabit more visual space and therefore be more visible than the same number of smaller flowers. Using only the measure of flower number to determine floral performance does not accurately portray the visual effectiveness of a space where floral visibility is a desirable feature; a measure of flower size in addition to flower number is required to compare the visibility of different floral forms.

Flower shape and size varies between species, with larger single flowers (e.g. Ranunculus repens) and tight grouping of many small flowers (e.g. Trifolium repens) having a greater visual area than small individual or ungrouped flowers (e.g. S. graminea). Previous work on flower size has used the size of the corolla as a measure of flower size (Sargent et al., 2007), however from head height the small individual flowers of species that are in tight groups or tightly clustered in inflorescences are difficult to distinguish. This was the case Achillea millefolium, Bellis perennis, Mentha pulegium, Phuopsis stylosa, Prunella vulgaris and Trifolium repens.

To provide for a useful method of comparison the flowers of $S$. graminea were used as a flower size reference species. The recorded flowers of all species were allocated a value representative of their size in relation to a single $5 \mathrm{~mm}$ diameter $S$. graminea flower with a floral area of $19.6 \mathrm{~mm}^{2}$. For example, a larger flower with a $10 \mathrm{~mm}$ diameter has a floral area 
of $78.5 \mathrm{~mm}^{2}$ and is therefore approximately equivalent to four $S$. graminea flowers. This method was modified for use in the field to allow the use of a hole template that measured diameters in whole millimetres. Stellaria equivalent values had been determined for each species by rounding to the nearest whole number the mean obtained by measuring the diameter of twenty flower heads taken randomly from the experimental plots. Where flowers did not occur in sufficient numbers in plots as occurred with A. millefolium, additional measurements were taken from plants growing in regularly mown turf adjacent to the experimental grounds. This was used to determine the Stellaria equivalent values shown in Table 1. The modified method used for determining whole number Stellaria values is given in further detail in the appendix.

For comparative purposes the number of flowers per species was multiplied by their Stellaria equivalent value to determine an approximate floral area and act as a measure of floral visibility. The floral visibility of individual lawns (Visibility) was the total in Stellaria equivalents (Stellarias) of all the species found within it. To directly compare the visibility of each group and treatment visibility per cut $(\mathrm{VpC})$ was used as an indicator of how floriferous each treatment and group appeared when averaged over time.

\section{Data analysis}

Comparisons of treatments between and within lawns were made using a general linear model with repeated measures ANOVA in MINITAB (Minitab., 2012). Where data sets did not follow a normal distribution prior to ANOVA data was transformed using either $\log (n+1)$, sin or arcsine square root transformations that met the assumptions of the terms.

\section{Environmental Conditions}


Autumn planting in the UK is common horticultural practice as soil temperature is usually sufficient to allow for root growth before the onset of winter (HTA, 2014). In line with common practice the grass-free lawns were planted out in October 2010. However immediately subsequent to planting unseasonal low temperatures were experienced at the experimental site, and were followed by an unusually severe winter that was recorded by the UK Meteorological Office as the worst British winter for 100 years (Anon, 2011b). The lowest temperature recorded at the experimental grounds was $-10.5^{\circ} \mathrm{C}$ (RHS hardiness rating H5). At the start of the first growing season in April 2011 the proportions of individual species within all groups was observed to have changed, particularly within the non-native group (Smith and Fellowes, 2014a). This initial winter period restructuring within groups influenced subsequent outcomes. The second growing season in 2012 was recorded by the UK Meteorological Office as the wettest British summer for 100 years (Anon, 2012).

\section{RESULTS}

\section{Mowing (Cut)}

2012 had a shorter growing season compared to 2011. In 2011 monthly cut lawns required mowing eight times and although at different times both height sensitive treatments required mowing nine times each. In 2012 monthly cut lawns were cut seven times and also at different times both height sensitive treatments were cut eleven times each. By comparison the University of Reading's turf lawn next to the experimental site was mown by grounds staff 29 times in 2011 and 26 times in 2012.

\section{Biomass}

The total biomass produced by grass-free lawns in both years was substantially greater than that produced by grass lawns over the same period in both mixed and native lawns. Non- 
native lawns produced a similar amount of biomass to grass lawns over the two year period (Table 2).

Biomass production was not seen to be constant in grass-free lawns and varied between years and between the temporal and height sensitive treatments. In 2011 monthly cut grass-free lawns produced significantly greater amounts of biomass than that produced in height sensitive treatments, with approximately a third greater produced in monthly cuts in all three grass-free groups.

In 2012 monthly cuts continued to produce significantly greater amounts of biomass in all grass-free groups, although the amount was substantially reduced compared to 2011. A reduction in biomass production in 2012 was also observed in all height sensitive treatments grass lawns

In 2012 height sensitive treated grass-free lawns were mown twice more than in 2011 and biomass was significantly reduced in all treatments. Total biomass within grass-free groups only was seen to be influenced by the year, group and the cut applied (Table 4). If the monthly cut lawns are withheld from the analysis since they have a different frequency of on biomass production $\left(F_{1,47}=0.67, P=0.424\right)$. Both the year $\left(F_{1,47}=67.4, P<0.001\right)$ and the group $\left(F_{2,47}=98.07, P<0.001\right)$ remain as significant influences on these two treatments.

In grass lawns annual biomass remained similar in all treatments over both years, although a significant reduction was apparent in $4 \mathrm{~cm}$ cut lawns in 2012. No specific influences on annual biomass were identified however biomass per cut was influenced by both the year, the 
cut applied, and an interaction between them with height specific cuts producing less biomass in year two (Table 3).

Flower Number

In 2011 flower number was greatest in lawns that produced the most biomass (Table 2), in all groups this was monthly cut lawns (Fig 2). Treatments applied in response to increasing height had been cut once more than monthly cuts and produced significantly fewer flowers. No relationship between the two responsive cut heights and flower production within grassfree groups was identified.

In 2012 even though monthly cut lawns had been cut once less than in 2011, in all monthly cut grass-free groups a reduced mean number of flowers was recorded, significantly so in both the mixed and non-native groups. Compared to 2011, biomass, frequency of mowing and floral production was reduced in all monthly cut grass-free groups (Table 2). In height sensitive treatments there was divergent behaviour between the mixed and native groups and the non-native group. In the mixed and native groups the frequency of mowing had increased and biomass had reduced, however flower numbers were not significantly different between years. In the non-native group which had also received a reduced frequency of mowing and shown a decrease in biomass, flower numbers had significantly increased.

In monthly cut lawns within the mixed and native groups the diversity of floral performance had substantially reduced between years and flower production was primarily from one species - T. repens (Fig 2). This reflected the changes to the component structure of monthly cut lawns, where the less frequent mowing was observed to favour a vigorous and tall growing Trifolium cultivar at the expense of shorter and less vigorous species. In height 
not occurred to the same degree, and floral contributions were made by greater numbers of species, particularly in the $4 \mathrm{~cm}$ native group.

In non-native lawns the highly floriferous and prostrate species Mazus reptans produced fewer flowers in taller growing monthly cut lawns and substantially more flowers in the height responsive cuts, particularly the lowest cut $2 \mathrm{~cm}$ lawns where its prostrate form was seen to be advantageous in avoiding the blade of the mower.

Flower number in grass lawns was not seen to be significantly different between treatments in 2011 and ranged between $85 \%$ and 95\% less than that found in grass-free lawns. In 2012 flower number had increased in monthly and $2 \mathrm{~cm}$ cut grass lawns. This was seen to be due to an expansion in cover of taller growing A. millefolium in monthly cut lawns and a notably prostrate form of B. perennis in the $2 \mathrm{~cm}$ cut lawns. Flower numbers in grass lawns in 2012 remained broadly in a similar range to 2011.

Flowers per unit biomass were calculated to determine if managing biomass via the different mowing regimes might prove be a useful tool in managing floral display. In grass-free lawns over the two year period this figure was found to be highly variable between treatments and groups, particularly in the first year after planting (Table 4).

\section{Visibility}

Here visibility is the number of flowers recorded multiplied by their Stellaria equivalent value and is measured in Stellarias. It is used to provide a generalised but useful measure of the petalled area of lawns.

Increased mean visibility in 2012 made all mixed and native lawns appear more floriferous compared to 2011; however this increase was only significant in $4 \mathrm{~cm}$ cut lawns in both 
groups (Fig 3). All treatments in mixed and native groups showed at least double the visibility found in the same treatments within the non-native group, indicating the visual usefulness of species with larger flowers. Mean visibility in both the mixed and native groups was not seen to be influenced by either the year or by the treatment applied (Table 3).

Visibility in all non-native lawns significantly increased between 2011 and 2012. This was seen to be influenced by the year and an interaction between the year and the cut. This coincided with an increase in $M$. reptans cover and flower number, and to a second year invasion by native species with larger flowers. Visibility in grass lawns also increased in all treatments although this was only significant in monthly cuts (Table 2).

Visibility per Cut (VpC) was seen to be greatest in mixed and native monthly cut lawns in both years (Table 2). $\mathrm{VpC}$ in $2 \mathrm{~cm}$ and $4 \mathrm{~cm}$ cut mixed and native lawns varied slightly but not significantly between years even though there was an increased frequency of cutting applied in 2012. The 4cm cut native group showed the highest level of VpC in both 2011 and 2012.

Non-native group VpC was significantly greater in 2012 than in 2011 in all treatments. The significant differences in $\mathrm{VpC}$ between treatments in 2011 remained consistent in 2012 (Table 2), with the year the only significant influence on $\mathrm{VpC}$ in the non-native group (Table 3). M. reptans was observed to increase its mean area of coverage and floral productivity during this period. In grass lawns VpC increased in monthly and 2cm cut lawns in 2012 but no significant influences were identified (Table 3).

\section{DISCUSSION}

From planting out in 2010, the lawns had two years to develop and this time period falls within the horticultural definition of perennial. This is a relatively short period of continuous development for a long term horticultural feature; however the aim of the study was to discover any significant differences in the initial perennial behaviour of the grass-free lawns 
in comparison to grass lawns when managed in the same way, and prior to any forms of additional aesthetic intervention that might be applied to an ornamental feature.

From the start of the first growing season all the grass-free lawns underwent changes that were seen to be influenced by the treatments applied, the species grouping and to a lesser extent the year (Table 4). This was reflected in the changes in biomass produced and the differences in overall floral performance both in flower number and floral visibility (Table 2). In the first year after planting, all grass-free groups with a monthly cut produced most biomass, most flowers and had the greatest amount of petalled area. For a grass-free lawn this would initially appear to be the ideal management regime if floral visibility were to be the only aesthetic consideration. However, monthly mowing produced taller more meadow-like lawns, it saw a reduction over time in the number of species that were seen to flower (Fig 2), there were also fewer species and greater amounts of bare soil visible within lawns (Smith and Fellowes, 2014a), and post-mowing the monthly cut lawns were aesthetically poor with many cut stems clearly visible.

The influence of monthly mowing on lawn component species and their visual performance was most evident in the second year with lawns visually dominated by one species only in all groups (Fig 3). This reflected the changes to the component structure of monthly cut lawns, where the less frequent mowing was observed to favour a vigorous and tall growing Trifolium cultivar at the expense of shorter and less vigorous species.

Remarkably in both years respectively the two height sensitive mowing regimes applied required the same number of total cuts for all grass-free groups, and also in both years the amount of total biomass collected from lawns cut to $2 \mathrm{~cm}$ was not significantly different from the total biomass collected from lawns cut to $4 \mathrm{~cm}$ (Table 2). As a method to maintain plant survival in lawns (Jacques and Edmond, 1952;Crider, 1955), the responsive mowing regimes 
specifically removed only the top third of the lawn, both the post-cut lawns retained an equivalent resource of two thirds from which to regrow before being cut again. This equivalent level of resource from which to regrow may go some way in accounting for the same annual requirement for mowing that was found in both years; however the biomass equivalency of the amount removed seems more likely to have been influenced by the specific height at which the cut is applied and its influence on the patterns of growth in the component species.

In mixed plant species populations it is difficult to directly determine the effect of a mowing regime, however mowing is generally recognised to reduce leaf area, reduce competition for light, influence apical dominance and plant architecture, and post-cut resource allocation in cut plants (Jameson, 1964). The height at which the cut is applied can influence subsequent regrowth (Schmid and Harper, 1985) and lower growing plants not as severely affected will continue their low growth (Graber, 1931), while mowing affected species may regrow with shorter internodes, greater stem density and other potentially dwarfing responses (De Kroons and Hutchings, 1995).

This is highly complex behaviour and although not specifically tested for, our observations of post cut aesthetics indicated that with the least amount of space in which to grow and expand, the $2 \mathrm{~cm}$ cut lawns may have produced lawn components with both shorter internodes and a greater stem density than that observed in $4 \mathrm{~cm}$ cut lawns. These characteristics were only clearly observed in the $T$. repens form that came to be the dominant species in mixed and native lawns, and the $2 \mathrm{~cm}$ vertical growth space of the $4 \mathrm{~cm}$ cut regime was observed to be being largely taken up by extended $T$. repens leaf petioles rather than by mixed species vegetation. The equivalent amounts of biomass produced by both treatments appear to reflect these variations in growth pattern and lawn density. In light of this complex behaviour and the number of significant factors and interactions found to influence flowers per unit biomass 
in grass-free lawns (Table 4), it seems unlikely that lawn biomass can be practicably managed to favour floral performance.

In 2012 despite a shorter growing season than 2011, the lawns required more frequent and additional mowing. The increase in the frequency and amount of mowing influenced biomass production in a negative manner with smaller amounts of biomass collected with each cut (Table 2). It seems likely that in manner similar to that observed in pasture, the more frequently a grass-free lawn is mown and growth interrupted, the less overall biomass is produced (Kennedy, 1950; Wagner, 1952 ). That there was sufficient continuous growth to triggering more cuts during 2012 than in 2011 is an indication that the qualities of the biomass produced can also be variable within any one year. The summer of 2012 was exceptionally wet, and the increased requirement for cutting suggests that growth was particularly lush in response to the unusually high level of moisture availability.

The cut applied to grass-free lawns significantly influenced floral outcomes (Table 4). In 2011 monthly cut lawns produced the greatest amount of flowers in all grass-free groups and with the exception of the $4 \mathrm{~cm}$ cut native group, within group responsively cut lawns had flower numbers that were not significantly different from each other. This suggests that the different frequency between fixed monthly and responsive application of mowing was influencing flower number. This also suggests that the timing of mowing and the length of the time period between cuts can influence flower number. Certainly cutting immediately prior to a species' flowering will negatively influence its floral outcomes, and conversely extended periods of plant growth between cuts potentially allows for greater floral development to be expressed. That the monthly and responsively cut $2 \mathrm{~cm}$ and $4 \mathrm{~cm}$ treatments differed by only one cut and showed such clear differences in floral productivity is indicative that just one cut can significantly influence floral outcomes. 
In 2012 the frequency of mowing increased in responsively cut treatments, however a significant drop in flower numbers was not observed. In mixed and native groups flower numbers were not significantly different compared to 2011 and in the non-native group flower numbers had increased. This appears to be due to the changes in the composition and structure within groups produced by the treatments applied. The treatments influenced flower number by changing the proportional composition of species within lawns over time (Smith \& Fellowes 2014). The richness of individual species contributing to flower number fell between years in all grass-free groups, mixed and native lawns becoming dominated by $T$. repens and non-native lawns by M. reptans (Fig 2). This two species domination in lawns largely restricted the period of floral visibility to their individual floral periods, a negative trait for a perennial feature, however their floral productivity was high and seen to compensate for the loss of floral performance by other species.

The best floral outcome in both years was observed to be the $4 \mathrm{~cm}$ cut native lawns where although floral variety was low in 2012 both mean flower number, flower number per cut and floral visibility were seen to be greatest within the responsively cut lawns (Table 2). That the lawns moved toward low floral diversity within two years also suggests that if greater floral diversity is the aim, that the initial construct of would benefit from taking into consideration the vigour of the species and forms used and that equal proportions at inception may not be the most suitable method.

Of the twenty species used as plug plants in equal measure at inception only six species were seen to make significant floral contributions over both years, only one of these $M$. reptans was non-native. This was initially due to poor winter survival rates among non-natives and subsequently to the competitive influence of $T$. repens within mixed and native lawns (Smith and Fellowes, 2014a). However the behaviour of the surviving species has shown that those 
native to the British Isles are likely to be a good choice as main constituents in a UK based

412 grass-free lawn, since they have proved to be both better suited climatically and to produce

413 flowers in sufficient number to give a higher level of floral visibility than the non-natives

414 used (Fig 3). Non-natives are not necessarily excluded from use in a grass-free lawn, since

415 they contribute to the community structure and amount of ground coverage achieved (Smith and Fellowes, 2014b). Non-native species survived in both the mixed and non-native lawns; however from these results it seems that used alone they are unlikely to be a good choice for maximum floral performance since floral visibility was lower compared to lawns that contained natives (Fig 3). This does not exclude the value that non-natives may have in a mixed origin lawn where they may extend the floral season and bring novelty and floral colour variations.

Within the grass lawns no significant influences were identified on total biomass, floral production or visibility, with only biomass per cut seen to be affected by the year and the mowing regime. That grass lawns do not behave in the same manner as grass-free lawns is indicative that the two formats are very different. Visually the internal structuring of species and the dynamics of grass based lawns is for the most part not clearly visible due to the visual

427 similarity of grasses, in grass-free lawns the continuous internal flux of mixed forbs is much more visually evident and is indeed a feature of the grass-free format.

- Grass-free lawns behave in a significantly different manner to grass lawns and aesthetic outcomes are very different.

- Mowing based on height averages is impracticable. Unlike grass lawns where a surface of roughly equal height is achievable, grass-free lawns produce an uneven surface. The use 
of a drop meter was required to determine an averaged measure of height. This methodology seems unlikely to be practical in everyday usage.

- Mowing should be applied when individual or groups of plants are observed to be

437 detrimentally affecting neighbours.

- Highly vigorous and tall varieties of T. repens should be avoided. Although producing lawns with a high floral visibility, this tends to be single species visibility and post cut aesthetics are poor due to extensive cut petioles post-mowing.

- British native species known to inhabit short grass were found to be the most suitable but not only choice. They had greater overall survival rates and better overall visual performance, with flowers being of sufficient size and produced in sufficient quantity to be more visually effective than the non-natives used.

- The height of the responsive cut applied did not directly influence flower production, rather it influenced the structure of the lawn community and subsequently the species source of flowers.

- Responsive mowing was seen to be the best method of management when a cut height of $4 \mathrm{~cm}$ was applied as this produced the best floral visibility and lawn species diversity.

- Specifically mowing on a fixed monthly basis was not a useful method as it was seen to favour vigorous and taller growing species, reduce floral diversity and produce a poor overall lawn aesthetic, particularly post cut.

- Visual performance may be influenced by manipulating the proportions of species used.

454 Larger proportions of smaller flowered species are required if they are to contribute similar amounts of floral visibility to larger flowered species.

456 Grass-free lawns retain the familiar lawn management technique of mowing and the traditional low cut aesthetic, they show human intention and ongoing care and additionally bring diverse foliage and floral performance to an area traditionally managed to be a planed 
monotone green. We used ten native and ten non-native species in our trials, but we see no reason why species number should remain so restricted, and believe that by reducing the need for mowing and enhancing the plant species diversity and floral resource of an otherwise traditionally flower poor area that grass-free lawns show a clear ecological motivation.

The use of plant species relevant to conditions found within the British Isles was suitable to our location and aims, although all of the species we trialled are not exclusive to the UK and can be found in lawns around the globe. The plug sized non-native plants we used at inception did not respond well to the unseasonably early start to the winter of 2011. Better developed plants are likely to have fared better since the selection was of a group of species marketed as hardy in horticulture in the UK. It is possible to speculate that by using the species we trialled and similar format relevant and climatically suitable species that grass-free lawns and appropriate mowing frequencies might be formulated to suit other regions, although it seems probable that outcomes will vary dependent on the local environment and the characteristics of the plants that might be used. Both the application of grass-free lawns beyond the UK and how pollinators and other lawn dwelling insects interact with them are areas that would benefit from further research.

Having obtained some insight on the type and characteristics of plant species to use, and found a potentially useful management methodology, we hope that this novel and unconventional approach to lawn space will prove to be ecologically useful, aesthetically pleasing and a socially acceptable lawn alternative.

\section{Acknowledgements}

We are grateful to the Royal Horticultural Society of Great Britain, the Finnis-Scott Foundation and the Garden Centre Association's Dick Allen Scholarship Fund for supporting this study. 


\begin{tabular}{|c|c|c|}
\hline \multicolumn{3}{|c|}{ Native Group } \\
\hline Latin & Common Name & $\begin{array}{c}\text { Stellaria } \\
\text { equivalent }\end{array}$ \\
\hline Achillea millefolium $\mathrm{L}$. & Yarrow & 80 \\
\hline Bellis perennis $\mathrm{L}$. & Daisy & 23 \\
\hline Pilosella officinarum Vaill. & Mouse-Ear Hawkweed & 19 \\
\hline Potentilla reptans $\mathrm{L}$. & Cinquefoil & 16 \\
\hline Prunella vulgaris $\mathrm{L}$. & Selfheal & 23 \\
\hline Ranunculus repens $\mathrm{L}$. & Creeping Buttercup & 19 \\
\hline Stellaria graminea $\mathrm{L}$. & Lesser Stitchwort & 1 \\
\hline Trifolium repens $\mathrm{L}$. & White Clover & 21 \\
\hline Veronica chamaedrys $\mathrm{L}$. & Germander Speedwell & 6 \\
\hline Viola odorata $\mathrm{L}$. & Sweet Violet & 23 \\
\hline \multicolumn{3}{|c|}{ Non-native Group } \\
\hline Diascia integerrima E.Mey. ex Benth. & Twinspur & 10 \\
\hline Lindernia grandiflora Nutt. & Blue Moneywort & 9 \\
\hline Lobelia angulata G.Forst & Pratia 'Tredwellii' & 7 \\
\hline Lobelia oligophylla (Wedd) Lammers & Hypsela & 5 \\
\hline Lobelia pedunculata $\mathrm{R} . \mathrm{Br}$. & Pratia "County Park' & 3 \\
\hline Mazus reptans N.E. Br. & Creeping Mazus & 5 \\
\hline Mentha pulegium $\mathrm{L}$. & Penny Royal & 7 \\
\hline Parochetus communis D.Don & Blue Oxalis & 8 \\
\hline Phuopsis stylosa (Trin.) Hook.f. ex B.D.Jacks. & Crosswort & 10 \\
\hline Pilosella aurantiaca (L.) F.W.Schultz \& Sch.Bip. & Fox \& Cubs & 48 \\
\hline
\end{tabular}

487 Table 1. Species groups and Stellaria values. 


\begin{tabular}{|c|c|c|c|c|c|c|c|c|c|c|c|c|c|c|c|}
\hline \multirow[t]{2}{*}{ GROUP } & \multirow[t]{2}{*}{ CUT } & \multicolumn{2}{|c|}{$\begin{array}{c}\text { Mean Annual } \\
\text { Biomass }(\mathrm{g}) \\
( \pm \mathrm{SE})\end{array}$} & \multicolumn{2}{|c|}{$\begin{array}{c}\text { Mean Biomass } \\
\text { per Cut }(\mathrm{g}) \\
( \pm \mathrm{SE})\end{array}$} & \multicolumn{2}{|c|}{$\begin{array}{l}\text { Mean Flower } \\
\text { Number } \\
( \pm \text { SE })\end{array}$} & \multicolumn{2}{|c|}{$\begin{array}{c}\text { Mean Flower } \\
\text { Number per Cut } \\
( \pm \text { SE })\end{array}$} & \multicolumn{2}{|c|}{$\begin{array}{l}\text { Mean Flowers } \\
\text { per Unit Biomass } \\
(\mathrm{g})( \pm \mathrm{SE})\end{array}$} & \multicolumn{2}{|c|}{$\begin{array}{c}\text { Mean Visibility } \\
\text { (Stellarias) } \\
( \pm S E)\end{array}$} & \multicolumn{2}{|c|}{$\begin{array}{c}\text { Mean Visibility } \\
\text { per Cut } \\
\text { (Stellarias) }( \pm \mathrm{SE})\end{array}$} \\
\hline & & 2011 & 2012 & 2011 & 2012 & 2011 & 2012 & 2011 & 2012 & 2011 & 2012 & 2011 & 2012 & 2011 & 2012 \\
\hline \multirow{3}{*}{ Mixed } & Monthly & 1027.9 & 723.7 & & 103.3 & 520 & & 65 & 56.3 & 0.51 & 0.56 & 7435 & 8068 & 929 & 1152 \\
\hline & $2 \mathrm{~cm}$ & $\begin{array}{l}(62.8) \\
689.3 \\
(24.4)\end{array}$ & $\begin{array}{l}(46.7) \\
625.1 \\
(31.9)\end{array}$ & $\begin{array}{l}(7.8) \\
76.5 \\
(2.7)\end{array}$ & $\begin{array}{l}(6.6) \\
56.8 \\
(2.9)\end{array}$ & $\begin{array}{l}(44.7) \\
309.5 \\
(29.0)\end{array}$ & $\begin{array}{l}(71.9) \\
321.5 \\
(14.8)\end{array}$ & $\begin{array}{l}(5.5) \\
34.3 \\
(3.2)\end{array}$ & $\begin{array}{c}(10.2) \\
29.2 \\
(1.3)\end{array}$ & $\begin{array}{c}(0.06) \\
0.70 \\
(0.06)\end{array}$ & $\begin{array}{c}(0.12) \\
0.52 \\
(0.03)\end{array}$ & $\begin{array}{l}(310) \\
5324 \\
(535)\end{array}$ & $\begin{array}{c}(1510) \\
6180 \\
(343)\end{array}$ & $\begin{array}{l}(38) \\
592 \\
(60)\end{array}$ & $\begin{array}{l}(215) \\
561 \\
(31)\end{array}$ \\
\hline & $4 \mathrm{~cm}$ & $\begin{array}{l}644.0 \\
(15.3)\end{array}$ & $\begin{array}{l}545.0 \\
(21.7)\end{array}$ & $\begin{array}{l}71.5 \\
(1.7)\end{array}$ & $\begin{array}{l}49.5 \\
(1.9)\end{array}$ & $\begin{array}{l}336.5 \\
(12.0)\end{array}$ & $\begin{array}{l}339.0 \\
(45.9)\end{array}$ & $\begin{array}{l}37.3 \\
(1.3)\end{array}$ & $\begin{array}{l}30.8 \\
(4.1)\end{array}$ & $\begin{array}{c}0.41 \\
(0.03)\end{array}$ & $\begin{array}{c}0.62 \\
(0.09)\end{array}$ & $\begin{array}{l}5500 \\
(172)\end{array}$ & $\begin{array}{l}6777 \\
(848) \\
\end{array}$ & $\begin{array}{l}611 \\
(19) \\
\end{array}$ & $\begin{array}{l}616 \\
(77)\end{array}$ \\
\hline \multirow{3}{*}{ Native } & Monthly & $\begin{array}{l}1048.4 \\
(21.3)\end{array}$ & $\begin{array}{l}696.3 \\
(28.8)\end{array}$ & $\begin{array}{l}131.0 \\
(2.6)\end{array}$ & $\begin{array}{l}99.4 \\
(4.1)\end{array}$ & $\begin{array}{l}479.2 \\
(25.5)\end{array}$ & $\begin{array}{l}434.5 \\
(62.1) \\
\end{array}$ & $\begin{array}{l}59.9 \\
(3.1) \\
\end{array}$ & $\begin{array}{r}62.7 \\
(8.8) \\
\end{array}$ & $\begin{array}{c}0.30 \\
(0.03)\end{array}$ & $\begin{array}{c}0.63 \\
(0.10)\end{array}$ & $\begin{array}{l}8730 \\
(639)\end{array}$ & $\begin{array}{c}9055 \\
(1284)\end{array}$ & $\begin{array}{c}1091 \\
(80)\end{array}$ & $\begin{array}{l}1293 \\
(183)\end{array}$ \\
\hline & $2 \mathrm{~cm}$ & $\begin{array}{l}718.1 \\
(36.1)\end{array}$ & $\begin{array}{l}602.1 \\
(29.5)\end{array}$ & $\begin{array}{l}79.8 \\
(4.0) \\
\end{array}$ & $\begin{array}{l}54.7 \\
(2.6) \\
\end{array}$ & $\begin{array}{l}303.5 \\
(33.5) \\
\end{array}$ & $\begin{array}{l}338.2 \\
(57.4)\end{array}$ & $\begin{array}{l}33.7 \\
(3.7) \\
\end{array}$ & $\begin{array}{l}30.7 \\
(5.2)\end{array}$ & $\begin{array}{c}0.43 \\
(0.07)\end{array}$ & $\begin{array}{c}0.55 \\
(0.07)\end{array}$ & $\begin{array}{l}6134 \\
(616) \\
\end{array}$ & $\begin{array}{r}7410 \\
(1327)\end{array}$ & $\begin{array}{l}681 \\
(68) \\
\end{array}$ & $\begin{array}{c}673 \\
(120)\end{array}$ \\
\hline & $4 \mathrm{~cm}$ & $\begin{array}{l}733.0 \\
(43.7)\end{array}$ & $\begin{array}{l}588.2 \\
(29.6)\end{array}$ & $\begin{array}{l}81.4 \\
(4.8)\end{array}$ & $\begin{array}{l}53.4 \\
(2.6)\end{array}$ & $\begin{array}{l}400.7 \\
(18.6)\end{array}$ & $\begin{array}{l}432.5 \\
(27.7)\end{array}$ & $\begin{array}{l}44.5 \\
(2.0)\end{array}$ & $\begin{array}{l}39.3 \\
(2.5)\end{array}$ & $\begin{array}{c}0.26 \\
(0.05)\end{array}$ & $\begin{array}{c}0.75 \\
(0.09)\end{array}$ & $\begin{array}{l}7900 \\
(226)\end{array}$ & $\begin{array}{c}9111 \\
(474)\end{array}$ & $\begin{array}{l}878 \\
(25)\end{array}$ & $\begin{array}{l}828 \\
(43)\end{array}$ \\
\hline \multirow{3}{*}{$\begin{array}{l}\text { Non- } \\
\text { Native }\end{array}$} & Monthly & $\begin{array}{l}786.7 \\
(172.3)\end{array}$ & $\begin{array}{l}391.9 \\
(16.6)\end{array}$ & $\begin{array}{c}98.3 \\
(21.5) \\
\end{array}$ & $\begin{array}{l}55.9 \\
(2.3) \\
\end{array}$ & $\begin{array}{c}264 \\
(20.1)\end{array}$ & $\begin{array}{l}201.2 \\
(24.8) \\
\end{array}$ & $\begin{array}{l}33.0 \\
(2.5) \\
\end{array}$ & $\begin{array}{r}28.7 \\
(3.5) \\
\end{array}$ & $\begin{array}{c}0.49 \\
(0.09)\end{array}$ & $\begin{array}{c}0.52 \\
(0.08)\end{array}$ & $\begin{array}{l}1624 \\
(287)\end{array}$ & $\begin{array}{l}2426 \\
(167) \\
\end{array}$ & $\begin{array}{l}203 \\
(36)\end{array}$ & $\begin{array}{l}347 \\
(24)\end{array}$ \\
\hline & $2 \mathrm{~cm}$ & $\begin{array}{l}457.8 \\
(24.3)\end{array}$ & $\begin{array}{l}287.9 \\
(13.4)\end{array}$ & $\begin{array}{l}50.8 \\
(2.7)\end{array}$ & $\begin{array}{l}26.1 \\
(1.2)\end{array}$ & $\begin{array}{c}184 \\
(21.5)\end{array}$ & $\begin{array}{l}368.2 \\
(22.5)\end{array}$ & $\begin{array}{l}20.4 \\
(2.3)\end{array}$ & $\begin{array}{l}33.4 \\
(2.0)\end{array}$ & $\begin{array}{c}0.88 \\
(0.01)\end{array}$ & $\begin{array}{c}1.28 \\
(0.08)\end{array}$ & $\begin{array}{l}1165 \\
(217)\end{array}$ & $\begin{array}{l}3176 \\
(321)\end{array}$ & $\begin{array}{l}129 \\
(24)\end{array}$ & $\begin{array}{l}289 \\
(29)\end{array}$ \\
\hline & $4 \mathrm{~cm}$ & $\begin{array}{l}450.1 \\
(25.0)\end{array}$ & $\begin{array}{l}333.3 \\
(25.8)\end{array}$ & $\begin{array}{l}50.0 \\
(2.7)\end{array}$ & $\begin{array}{l}30.3 \\
(2.3) \\
\end{array}$ & $\begin{array}{l}158.5 \\
(12.7)\end{array}$ & $\begin{array}{l}271.7 \\
(48.9)\end{array}$ & $\begin{array}{l}17.6 \\
(1.4) \\
\end{array}$ & $\begin{array}{l}24.7 \\
(4.4)\end{array}$ & $\begin{array}{c}0.36 \\
(0.05)\end{array}$ & $\begin{array}{c}0.86 \\
(0.20)\end{array}$ & $\begin{array}{l}714 \\
(24)\end{array}$ & $\begin{array}{l}2884 \\
(319)\end{array}$ & $\begin{array}{l}79 \\
(3)\end{array}$ & $\begin{array}{l}262 \\
(29)\end{array}$ \\
\hline \multirow{3}{*}{ Grass } & Monthly & $\begin{array}{l}507.2 \\
(50.0)\end{array}$ & $\begin{array}{l}451.3 \\
(65.3) \\
\end{array}$ & $\begin{array}{l}63.4 \\
(6.2) \\
\end{array}$ & $\begin{array}{l}64.4 \\
(9.3) \\
\end{array}$ & $\begin{array}{c}23.2 \\
(10.6) \\
\end{array}$ & $\begin{array}{l}51.2 \\
(9.8) \\
\end{array}$ & $\begin{array}{c}2.9 \\
(1.3) \\
\end{array}$ & $\begin{array}{c}7.3 \\
(1.4) \\
\end{array}$ & $\begin{array}{c}0.06 \\
(0.03)\end{array}$ & $\begin{array}{c}0.13 \\
(0.04)\end{array}$ & $\begin{array}{c}429 \\
(152) \\
\end{array}$ & $\begin{array}{r}1463 \\
(577)\end{array}$ & $\begin{array}{c}54 \\
(19) \\
\end{array}$ & $\begin{array}{l}209 \\
(82) \\
\end{array}$ \\
\hline & $2 \mathrm{~cm}$ & $\begin{array}{l}417.6 \\
(40.7)\end{array}$ & $\begin{array}{l}461.7 \\
(72.8)\end{array}$ & $\begin{array}{l}46.4 \\
(4.5) \\
\end{array}$ & $\begin{array}{l}41.9 \\
(6.6) \\
\end{array}$ & $\begin{array}{l}20.5 \\
(7.9)\end{array}$ & $\begin{array}{l}53.0 \\
17.9 \\
\end{array}$ & $\begin{array}{c}2.2 \\
(0.8) \\
\end{array}$ & $\begin{array}{c}4.8 \\
(1.6) \\
\end{array}$ & $\begin{array}{c}0.05 \\
(0.02)\end{array}$ & $\begin{array}{c}0.14 \\
(0.06)\end{array}$ & $\begin{array}{c}453 \\
(183) \\
\end{array}$ & $\begin{array}{r}1090 \\
(639) \\
\end{array}$ & $\begin{array}{c}50 \\
(20)\end{array}$ & $\begin{array}{c}99 \\
(58)\end{array}$ \\
\hline & $4 \mathrm{~cm}$ & $\begin{array}{l}411.7 \\
(21.9)\end{array}$ & $\begin{array}{l}317.5 \\
(16.9) \\
\end{array}$ & $\begin{array}{l}45.7 \\
(2.4) \\
\end{array}$ & $\begin{array}{l}28.8 \\
(1.5) \\
\end{array}$ & $\begin{array}{c}19 \\
(4.1) \\
\end{array}$ & $\begin{array}{r}17.2 \\
(5.9) \\
\end{array}$ & $\begin{array}{c}2.1 \\
(0.4) \\
\end{array}$ & $\begin{array}{c}1.5 \\
(0.5) \\
\end{array}$ & $\begin{array}{c}0.04 \\
(0.01)\end{array}$ & $\begin{array}{c}0.06 \\
(0.02) \\
\end{array}$ & $\begin{array}{c}396 \\
(103) \\
\end{array}$ & $\begin{array}{c}450 \\
(197) \\
\end{array}$ & $\begin{array}{c}44 \\
(12) \\
\end{array}$ & $\begin{array}{c}41 \\
(18) \\
\end{array}$ \\
\hline
\end{tabular}

489 Table 2 Biomass and floral performance by group and cut for $2011 \& 2012$.

\begin{tabular}{|c|c|c|c|c|c|c|c|c|}
\hline GROUP & FACTOR & $\begin{array}{c}\text { Mean } \\
\text { Annual } \\
\text { Biomass (g) }\end{array}$ & $\begin{array}{c}\text { Mean } \\
\text { Biomass per } \\
\text { Cut (g) }\end{array}$ & $\begin{array}{l}\text { Mean } \\
\text { Flower } \\
\text { Number }\end{array}$ & $\begin{array}{c}\text { Mean } \\
\text { Flower } \\
\text { Number per } \\
\text { Cut }\end{array}$ & $\begin{array}{c}\text { Mean } \\
\text { Flowers per } \\
\text { Unit } \\
\text { Biomass (g) }\end{array}$ & $\begin{array}{c}\text { Mean } \\
\text { Visibility } \\
\text { (Stellarias) }\end{array}$ & $\begin{array}{c}\text { Mean } \\
\text { Visibility } \\
\text { per Cut } \\
\text { (Stellarias) }\end{array}$ \\
\hline \multirow{3}{*}{ Mixed } & Year & $\begin{array}{c}P=0.002 \\
F 1,23=118.05\end{array}$ & $\begin{array}{c}P<0.001 \\
F 1,23=242.07\end{array}$ & ns & ns & ns & ns & ns \\
\hline & Cut & $\begin{array}{c}P<0.001 \\
F 2,23=17.01\end{array}$ & $\begin{array}{c}P<0.001 \\
F 2,23=57.67\end{array}$ & $\begin{array}{c}P=0.007 \\
F 2,23=0.72\end{array}$ & $\begin{array}{c}P<0.001 \\
F 2,23=33.60\end{array}$ & ns & ns & $\begin{array}{c}P=0.001 \\
F 2,23=18.21\end{array}$ \\
\hline & Year*Cut & $\begin{array}{c}P=0.001 \\
F 2,23=15.62\end{array}$ & ns & ns & ns & ns & ns & ns \\
\hline \multirow{3}{*}{ Native } & Year & $\begin{array}{c}P<0.001 \\
F 1,23=93.36\end{array}$ & $\begin{array}{c}P<0.001 \\
F 1,23=93.36\end{array}$ & ns & ns & $\begin{array}{c}P<0.001 \\
F 1,23=81.89\end{array}$ & ns & ns \\
\hline & Cut & $\begin{array}{c}P=0.001 \\
F 2,23=17.91\end{array}$ & $\begin{array}{c}P<0.001 \\
F 2,23=77.04\end{array}$ & ns & $\begin{array}{c}P=0.003 \\
F 2,23=12.30\end{array}$ & ns & ns & $\begin{array}{c}P=0.005 \\
F 2,23=7.93\end{array}$ \\
\hline & Year*Cut & ns & ns & ns & ns & $\begin{array}{c}P=0.005 \\
F 2,23=9.90\end{array}$ & ns & ns \\
\hline \multirow{3}{*}{$\begin{array}{l}\text { Non- } \\
\text { Native }\end{array}$} & Year & $\begin{array}{c}P<0.001 \\
F 1,23=34.71\end{array}$ & $\begin{array}{c}P<0.001 \\
F 1,23=49.20\end{array}$ & ns & ns & ns & $\begin{array}{c}P<0.001 \\
F 1,23=106.46\end{array}$ & $\begin{array}{c}\mathrm{P}<0.001 \\
F 1,23=74.16\end{array}$ \\
\hline & Cut & $\begin{array}{c}P=0.004 \\
F 2,23=10.86\end{array}$ & $\begin{array}{c}P<0.001 \\
F 2,23=33.87\end{array}$ & ns & ns & $\begin{array}{c}P=0.001 \\
F 2,23=15.76\end{array}$ & ns & ns \\
\hline & Year*Cut & ns & ns & $\begin{array}{c}P=0.009 \\
F 2,23=8.37\end{array}$ & ns & ns & $\begin{array}{c}P=0.014 \\
F 2,23=7.20\end{array}$ & ns \\
\hline \multirow{3}{*}{ Grass } & Year & ns & $\begin{array}{c}P=0.003 \\
F 1,23=16.08\end{array}$ & ns & ns & ns & ns & $\mathrm{ns}$ \\
\hline & Cut & ns & $\begin{array}{c}P=0.012 \\
F 2,23=7.61\end{array}$ & ns & ns & ns & ns & ns \\
\hline & Year*Cut & $\mathrm{ns}$ & $\begin{array}{c}P=0.010 \\
F 2,23=7.94\end{array}$ & ns & ns & ns & $\mathrm{ns}$ & ns \\
\hline
\end{tabular}


Table 3. Results of ANOVA showing within group significant influences on biomass and

493 floral performance between $2011 \& 2012$.

494

495

\begin{tabular}{|l|c|c|c|c|c|c|c|}
\hline $\begin{array}{c}\text { GRASS-FREE } \\
\text { LAWNS }\end{array}$ & Year & Group & Cut & $\begin{array}{c}\text { Year } \\
{ }^{*} \text { Group }\end{array}$ & $\begin{array}{c}\text { Year } \\
{ }^{*} \text { Cut }\end{array}$ & $\begin{array}{c}\text { Group } \\
{ }^{*} \text { Cut }\end{array}$ & $\begin{array}{c}\text { Year } \\
\text { *Group*Cut }^{*}\end{array}$ \\
\hline Total Biomass & $\begin{array}{c}P<0.001 \\
F_{1,71}=110.5\end{array}$ & $\begin{array}{c}P<0.001 \\
F_{2,71}=103.1\end{array}$ & $\begin{array}{c}P<0.001 \\
F_{2,71}=39.4\end{array}$ & ns & ns & ns & ns \\
\hline $\begin{array}{l}\text { Total Biomass } \\
\text { per Cut }\end{array}$ & $\begin{array}{c}P<0.001 \\
F_{1,71}=182.1\end{array}$ & $\begin{array}{c}P<0.001 \\
F_{2,71}=103.1\end{array}$ & $\begin{array}{c}P<0.001 \\
F_{2,71}=141.9\end{array}$ & ns & ns & ns & ns \\
\hline Total Flowers & ns & $\begin{array}{c}P<0.001 \\
F_{2,71}=36.6\end{array}$ & $\begin{array}{c}P=0.001 \\
F_{2,71}=8.6\end{array}$ & ns & ns & $\begin{array}{c}P=0.002 \\
F_{2,71}=5.8\end{array}$ & ns \\
\hline $\begin{array}{l}\text { Total Flowers } \\
\text { per Cut }\end{array}$ & $\mathrm{ns}$ & $\begin{array}{c}P<0.001 \\
F_{2,71}=39.3\end{array}$ & $\begin{array}{c}P<0.001 \\
F_{2,71}=33.6\end{array}$ & $\mathrm{~ns}$ & $\mathrm{~ns}$ & $\mathrm{~ns}$ & $\mathrm{~ns}$ \\
\hline $\begin{array}{l}\text { Total Flowers } \\
\text { per unit Biomass }\end{array}$ & $\begin{array}{c}P<0.001 \\
F_{1,71}=32.8\end{array}$ & $\begin{array}{c}P=0.001 \\
F_{2,71}=8.8\end{array}$ & $\begin{array}{c}P=0.001 \\
F_{2,71}=9.8\end{array}$ & $\begin{array}{c}P=0.002 \\
F_{2,71}=7.8\end{array}$ & $\begin{array}{c}P=0.001 \\
F_{2,71}=8.3\end{array}$ & $\mathrm{~ns}$ & $\mathrm{~ns}$ \\
\hline Total Visibility & $\begin{array}{c}P=0.001 \\
F_{1,71}=13.4\end{array}$ & $\begin{array}{c}P<0.001 \\
F_{2,71}=127.1\end{array}$ & $\begin{array}{c}P<0.009 \\
F_{2,71}=5.6\end{array}$ & $\mathrm{~ns}$ & $\mathrm{~ns}$ & $\mathrm{~ns}$ & $\mathrm{~ns}$ \\
\hline $\begin{array}{l}\text { Total Visibility } \\
\text { per Cut }\end{array}$ & $\mathrm{ns}$ & $\begin{array}{c}P<0.001 \\
F_{2,71}=195.4\end{array}$ & $\begin{array}{c}P<0.001 \\
F_{2,71}=29.4\end{array}$ & $\begin{array}{c}P=0.001 \\
F_{2,71}=8.6\end{array}$ & $\mathrm{~ns}$ & $\mathrm{~ns}$ & $\mathrm{~ns}$ \\
\hline
\end{tabular}

496

497 Table 4. Results of ANOVA showing significance influences on biomass and floral performance in grass-free lawns between $2011 \& 2012$. 


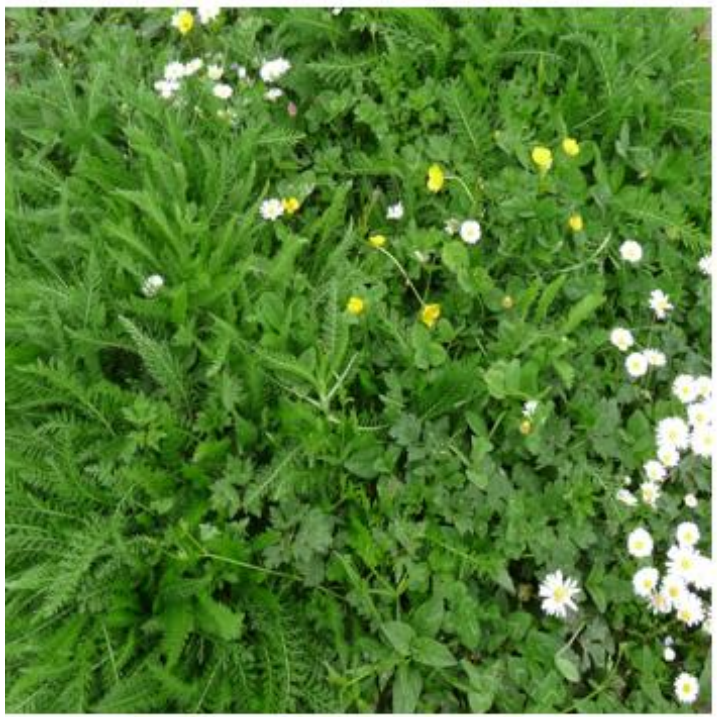

Native Lawn

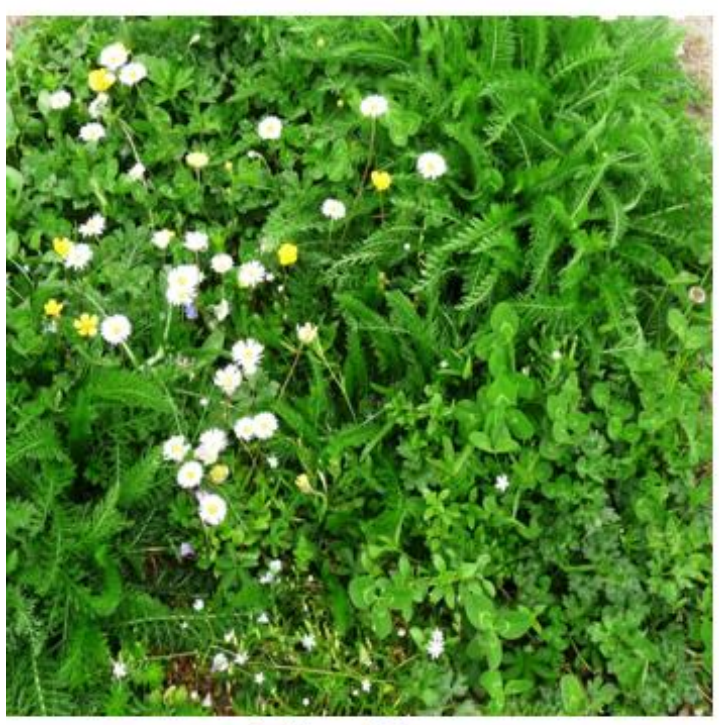

Mixed Lawn

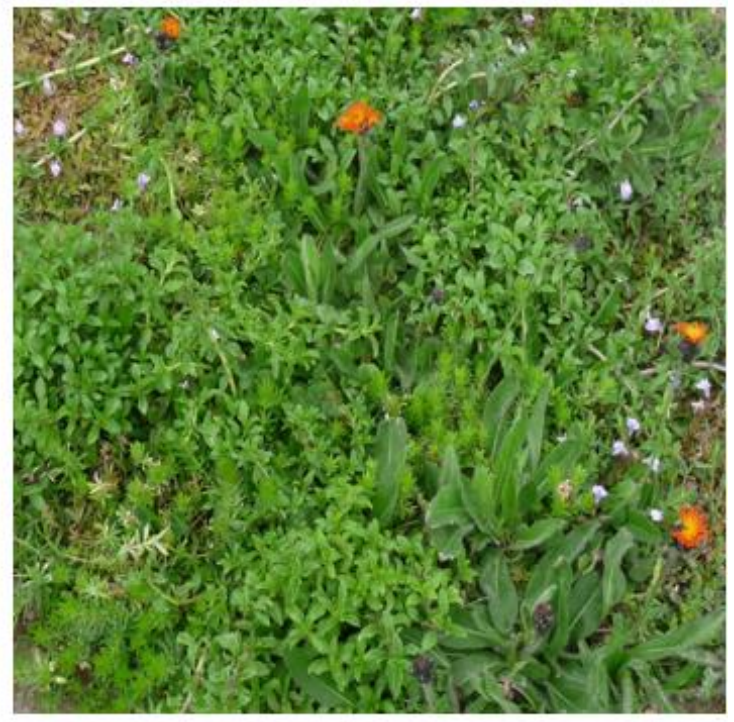

Non-native Lawn

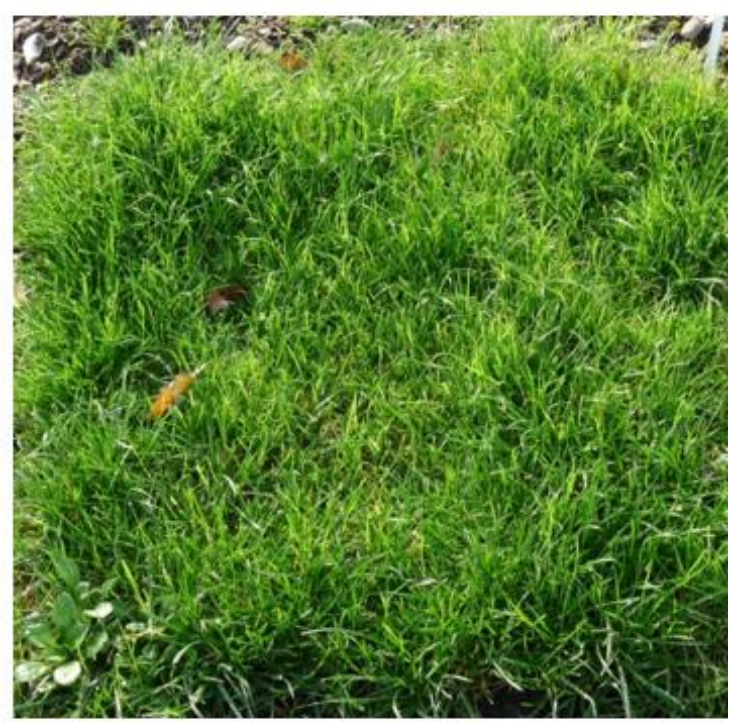

Grass Lawn

500 Fig 1. Examples of the four experimental lawn groups. Images created $26^{\text {th }}$ May 2011. 


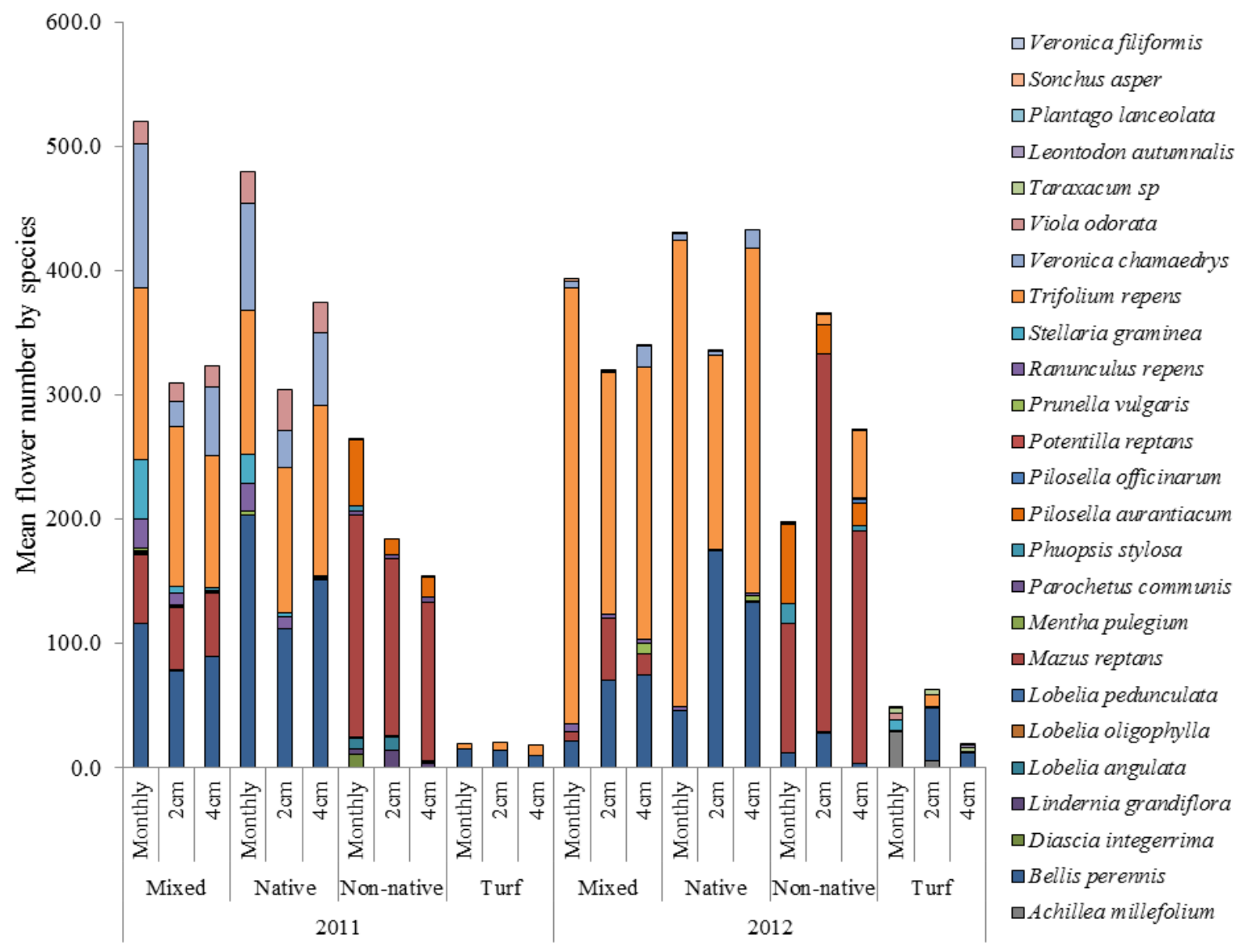

503 Fig 2. Mean flower number within groups by species $2011 \& 2012$. 


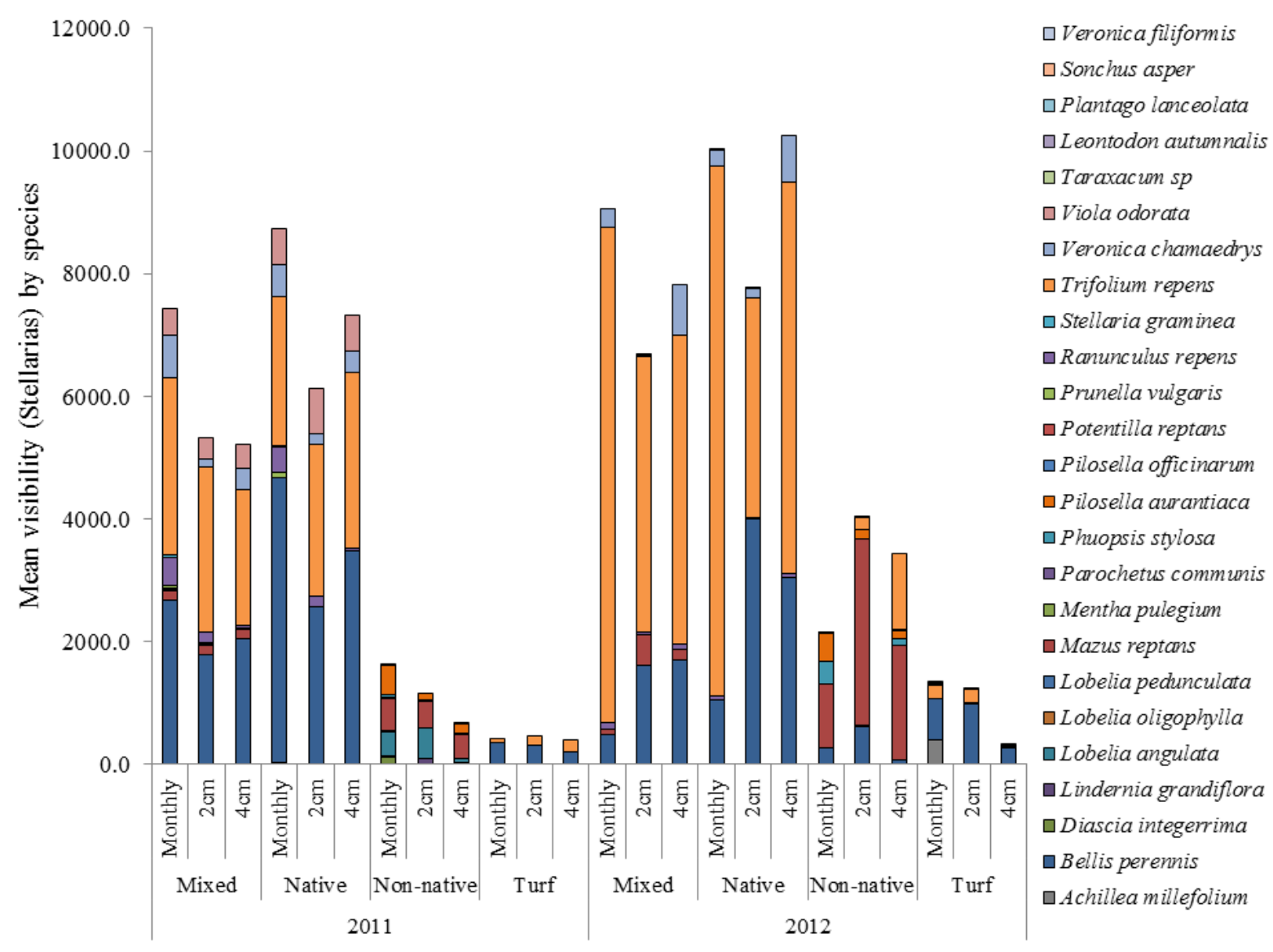

$506 \quad$ Fig 3. Mean visibility within groups by species (Stellarias) 2011 \& 2012. 
521 Appendix A

522 Stellaria Equivalents.

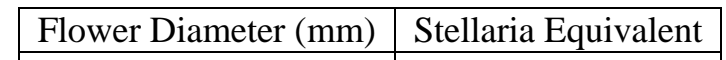

\begin{tabular}{|c|c|}
\hline 5 & 1 \\
\hline 7 & 2 \\
\hline 9 & 3 \\
\hline 10 & 4 \\
\hline
\end{tabular}

\begin{tabular}{|c|c|}
\hline 11 & 5 \\
\hline 12 & 6 \\
\hline 13 & 7 \\
\hline 14 & 8 \\
\hline 15 & 9 \\
\hline
\end{tabular}

\begin{tabular}{|c|c|}
\hline 15 & 9 \\
\hline 16 & 10 \\
\hline 17 & 11 \\
\hline 18 & 13 \\
\hline 19 & 14 \\
\hline 20 & 16 \\
\hline
\end{tabular}

\begin{tabular}{|c|c|}
\hline 20 & 14 \\
\hline 21 & 16 \\
\hline 22 & 17 \\
\hline 23 & 19 \\
\hline 24 & 21 \\
\hline 25 & 23 \\
\hline
\end{tabular}

\begin{tabular}{|l|l|}
\hline 23 & 21 \\
\hline 24 & 23 \\
\hline 25 & 25 \\
\hline 26 & 27 \\
\hline 27 & 29 \\
\hline 28 & 32 \\
\hline
\end{tabular}


$524 \quad$ Rational and methodology for creating whole number values for Stellaria equivalents.

525 It quickly becomes apparent that when looking at a grouping of different plant species in flower at the same time that flowers with a larger size are immediately more visible, they take up more visual area.

527 This feature is commonly used in garden design where larger flowers can be placed further from the 528 viewer than smaller ones to maintain the illusion of a constant flower size over a distance. This

529 technique is usually a judgement made by eye and experience.

530 To ensure ease of use and a level of repeatability in representing the visibility of the flowers it was 531 necessary to construct a method that was relevant and could be extrapolated from data collected easily 532 in the field.

533 From experience Stellaria graminea flowers of approximately $5 \mathrm{~mm}$ diameter were the smallest 534 visible flowers from head height and therefore chosen as a reference flower size.

535 The question then is how many Stellaria flowers ( $5 \mathrm{~mm}$ diameter circles) can fit into the visible area of the flower being measured to make a comparison. This initially presents a series of challenges as there is great variety in flower size, shape, form and distribution on variously structured flowering inflorescences. However, since only an approximate value is required, by using a template of circle diameters it is possible to measure the diameter of a single or clustered group of flowers in the field by seeing which diameter circle the flower can easily fit through at its widest point.

541 Not all measured sizes allow for a fit as a whole number. For example a sample flower or grouped 542 tiny flowers that can fit through a circle at its widest point with a diameter of $8 \mathrm{~mm}$ is equivalent to 1.6 543 Stellaria flowers. However, values that are not in units of $5 \mathrm{~mm}$ are not required since measurements 544 below $5 \mathrm{~mm}$ as mentioned previously are not clearly visible, i.e. the 0.6 of a Stellaria is difficult to 545 distinguish, the measurements needs to be clearly for either 1 or 2 Stellaria flower equivalents.

546 Whole unit Stellaria equivalents are required and make the basis for any determination of size.

547 Using $A=\pi r^{2}$ the area of 1 Stellaria with a radius of $2.5 \mathrm{~mm}=19.63495 \mathrm{~mm}^{2}$ 
$550 \quad$ For 11 Stellarias: $11 \times 19.63495=215.9845 \mathrm{~mm}^{2}$

$551 \quad$ Using $\quad r^{2}=\frac{A}{\pi}$ (to determine the radius ${ }^{2}$ )

552

553

$$
68.75=\frac{215.9845}{\pi}
$$

$\sqrt{68.75}=8.291562$ (radius)

$554 \quad$ Radius $\times 2=$ Diameter $=16.58312395 \mathrm{~mm}$

555 This is allocated as follows:

\begin{tabular}{|c|c|c|c|c|}
\hline $\begin{array}{c}\text { Flower Diameter } \\
(\mathrm{mm})\end{array}$ & $\begin{array}{c}\text { Flower Radius } \\
(\mathrm{mm})\end{array}$ & $\begin{array}{c}\text { Flower Area } \\
(\mathrm{mm})\end{array}$ & Stellarias & Amended \\
\hline 16.58312395 & 8.291561976 & 215.984495 & 11 & NA \\
\hline
\end{tabular}

556

557 Although this provides for whole Stellaria values having a flower measuring template with such

558 precise diameters is not practicable. Whole diameters are more useful, so they need to be rounded to

559 the nearest whole number e.g.

\begin{tabular}{|c|c|c|c|c|}
\hline Diameter (mm) & Radius $(\mathrm{mm})$ & Area $(\mathrm{mm})$ & Stellarias & Amended \\
\hline $\mathbf{1 7}$ & 8.291561976 & 215.984495 & 11 & NA \\
\hline
\end{tabular}

560

561 This changes the Diameter to $17 \mathrm{~mm}$. Although in this case this is for 11 Stellarias this value is also

562 shared by 12 Stellarias since they produce a $17.32 \mathrm{~mm}$ diameter. See below.

563 To account for this the lowest Stellaria value is used so the amended value for 12 Stellarias becomes

564 11. The lower value is preferentially used since with increasing flower size the visual difference - the

565 perceived change in visibility, becomes less distinguishable i.e. the visual difference between a $10 \mathrm{~mm}$ 
567 that between a $110 \mathrm{~mm}$ flower and a $120 \mathrm{~mm}$ flower (an increase of $8.4 \%$ ).

568 Example:

\begin{tabular}{|c|c|c|c|c|}
\hline Diameter $(\mathrm{mm})$ & Radius $(\mathrm{mm})$ & Area $(\mathrm{mm})$ & Stellarias & Amended \\
\hline 14.14213562 & 7.071067812 & 157.079633 & 8 & na \\
\hline 15.00 & 7.5 & 176.714587 & 9 & na \\
\hline 15.8113883 & 7.90569415 & 196.349541 & 10 & na \\
\hline 16.58312395 & 8.291561976 & 215.984495 & 11 & na \\
\hline 17.32050808 & 8.660254038 & 235.619449 & 12 & na \\
\hline
\end{tabular}

569

\begin{tabular}{|c|c|c|c|c|}
\hline $\begin{array}{c}\text { AMENDED } \\
\text { Diameter (mm) } \\
\text { rounded to nearest } \\
\text { whole number }\end{array}$ & Radius (mm) & Area (mm) & Stellarias & $\begin{array}{c}\text { AMENDED } \\
\text { Stellarias rounded } \\
\text { down to match } \\
\text { amended diameter }\end{array}$ \\
\hline 14 & 7.071067812 & 157.079633 & 8 & 8 \\
\hline 15 & 7.5 & 176.714587 & 9 & 10 \\
\hline 16 & 7.90569415 & 196.349541 & 10 & 11 \\
\hline 17 & 8.291561976 & 215.984495 & 11 & 11 \\
\hline 17 & 8.660254038 & 235.619449 & 12 & \\
\hline
\end{tabular}

570

571 Where the inflorescence being measured is longer than it is wide the length of the inflorescence

572 should be used to determine the diameter and a visual assessment made of how many inflorescences

573 might approximately fill the remaining space within the circle the diameter proscribes. The visibility

574 score can be adjusted by division to account for this.

575

576 
578

Allen, W., Balmori, D. \& Haeg, F. 2010. Edible Estates: Attack on the Front Lawn., Metropolis Books.

Anon. 2011a. Lawn Alternatives. Climate Appropriate Grasses and Ground Covers. Santa Barbara Water Conservation Information Document. Available: http://www.sbwater.org/documents/Climate\%20Appropriate\%20Grasses.pdf [Accessed 01/07/2011].

Anon. 2011b. Winter 2010/11 Online Report. Available: http://www.metoffice.gov.uk/climate/uk/2011/winter.html [Accessed 12/05/2011].

Anon. 2012. UK Climate: Summer 2012 Online Report. Available: http://www.metoffice.gov.uk/climate/uk/2012/summer.html [Accessed 01/12/2012].

Barnhart, S. K. 1998. Estimating available pasture forage. Online report. Available: http://www.extension.iastate.edu/Publications/PM1758.pdf [Accessed 21/11/2010].

Borman, F. H., Balmori, D. \& Geballe, T. G. 2001. Redesigning the American Lawn. A Search for Environmental Harmony., New Haven \& London, Yale University Press.

Brown, C. S. 2011. Native Plants \& Wildlife Gardens. Professional contribution web resource. [Online]. Available: http://nativeplantwildlifegarden.com/ [Accessed 23/09/2011].

Byrne, L. B. Of looks, laws and lawns: How human aesthetic preferences influence landscape management, public policies and urban ecosystems. In: LABAND, D., ed. Emerging Issues Along Urban-Rural Interfaces: Linking Science and Society., 2005 Auburn University, Auburn, AL., 42-46.

Clayton, S. 2007. Domesticated nature: Motivations for gardening and perceptions of environmental impact. Journal of Environmental Psychology., 27, 215-224.

Cook, T. W. 1993. Low Maintenance Turf. Hardy Plant Society of Oregon, 9(1), 9-15. 
602

603

604

605

606

607

608

609

610

611

612

613

614

615

616

617

618

619

620

621

622

623

624

625

Crider, F. J. 1955. Root growth stoppage resulting from defoliation of grass. Technical Bulletin 1102.: US Department of Agriculture.

Daniels, S. 1995. The Wild Lawn Handbook. Alternatives to the traditional front lawn. , Macmillan.

De Kroons, H. \& Hutchings, M. J. 1995. Morphological plasticity in clonal plants: the foraging concept reconsidered. Journal of Ecology., 83, 143-152

Feagan, R. B. 2001. Reading private garden space:competing geographic identities at the level of the lawn. Philosophy \& Geography, 4, 79-95.

Feagan, R. B. \& Ripmeester, M. 1999. Contesting Natural(ised) Lawns: A Geography of Private Green Space in the Niagra Region. Urban Geography, 20, 617-634.

Fogelfors, H. 1983. Grass in cultivated areas - agriculture, parks and gardens, Uppsala, Sveriges lantbruksuniv.

Fort, T. 2000. The Grass is Greener. London: Harper Collins.

Gaston, K. J., Fuller, R. A., Loram, A., Macdonald, C., Power, S. \& Dempsey, N. 2007. Urban domestic gardens (XI): variation in urban wildlife gardening in the United Kingdom. Biodiversity Conservation, 16, 3227-3238.

Godefroid, S. 2001. Temporal analysis of the Brussels flora as indicator for changing environmental quality. Landscape and Urban Planning., 52, 203-224.

Graber, L. F. 1931. Food reserves in relation to other factors limiting the growth of grasses. Plant Physiology., 6, 43-71.

Hadden, E. J. 2012. Beautiful No-Mow Yards. 50 Amazing Lawn Alternatives, Portland, Timber Press.

Helfand, G. E., Park, J. S., Nassauer, J. I. \& Kosek, S. 2006. The economics of native plants in residential landscape designs. Landscape and Urban Planning., 78, 229-240. 
Henderson, S. P. B., Perkins, Nathan. H., Nelischer, Maurice. 1998. Residential lawn alternatives: a study of their distribution, form and structure. Landscape and Urban Planning, 42, $135-145$.

Hta. 2014. Autumn Planting. Nature's natural time to plant. [Online]. Horticultural Trades Association. Available: http://www.the-hta.org.uk/page.php?pageid=959 [Accessed $03 / 01 / 2014$

Ignatieva, M. E. \& Stewart, G. H. 2009. Homogeneity of urban biotopes and similarity of landscape design language in former colonial cities. . In: MCDONNELL, M. J., HAHS, A. K. \& BREUSTE, J. H. (eds.) Ecology of cities and towns : a comparative approach. p399-421. Cambridge. UK.: Cambridge University Press.

Jacques, W. A. \& Edmond, D. B. 1952. Root development in some common New Zealand pasture plants V. The effect of defoliation and root pruning on cocksfoot (Dactylis glomerata) and perennial rye-grass (Lolium perenne). New Zealand Journal of Science., 34, 231-248.

Jameson, D. A. 1964. Responses of individual plants to harvesting. The Botanical Review., $29.4,532-594$.

Jefferson, R. 2007. Wildflower meadows:how to create one in your garden. Natural England.

Kennedy, W. K. 1950. Simulated grazing treatments, effect on yield, botanical composition, and chemical composition of a permanent pasture. Cornell University. Agricultural Experiment Station.

Kiesling, F. M., Manning, C.M. 2010. How green is your thumb? Environmental gardening identity and ecological gardening practices. Journal of Environmental Psychology, 30, $315-327$.

Macinnis, P. 2009. The Lawn. A Social History., Millers Point. NSW., Murdock Books. 
Marinelli, J. 1993. The Natural Lawn \& Alternatives (Plants \& Gardens), Brooklyn, New York., Brooklyn Botanic Garden Inc.

Mcmahan, L. R. 2006. Understanding cultural reasons for the increase in both restoration efforts and gardening with native plants. Native Plants Journal, 7, 31-34.

Minitab. 2012. Minitab16 Statistical Software. Minitab Inc.

Müller, N. 1990. Lawns in German cities. A phytosociological comparison. In: SUKOPP, H. (ed.) Urban Ecology. The Hague. The Netherlands.: SPB Academic Publishing.

Nassauer, J. I. 1995. Messy Ecosystems, Orderly Frames. Landscape Journal, 14, 161-170.

Nassauer, J. I., Wang, Z. \& Dayrell, E. 2009. What will the neighbours think? Cultural norms and ecological design. Landscape and Urban Planning, 92, 282-292.

Pickett, S. T. A., Cadenasso, M. L., Grove, J. M., Nilon, C. H., Pouyat, R. V., Zipperer, W. C. \& Costanza, R. 2001. Urban Ecological Systems: linking terrestrial ecological, physical and socioeconomic components of metropolitan areas. Annual Review of Ecology and Systematics, 32, 127-157.

Piekielek, B. N. 2003. Suburban Dynamics of Lawn Care. Masters Thesis, University of Georgia, Athens GA.

Purchase, M. 1997. Factors that influence the adoption of lawn alternative residential landscapes. Masters Thesis, University of Guelph. Ontario.

Rayburn, E., Lozier, J. 2003. A falling plate meter for estimating pasture forage mass. Available: http://www.wvu.edu/ agexten/forglvst/fallplate.pdf [Accessed 21/12/2010].

Robbins, P. 2007. Lawn People. How Grasses, Weeds and Chemicals Make Us Who We Are., Philadelphia, Temple Univertsity Press.

Robbins, P., Sharp, Julie. 2003. The Lawn-Chemical Economy and Its Discontents. Antipode, $35,955-979$. 
Ryall, C. \& Hatherell, P. 2003. A Survey of Strategies Adopted by UK Wildlife Trusts in the Promotion of Gardening for Wildlife. Environmentalist, 23, 81-87.

Sargent, R. D., Goodwillie, C., Kalisz, S. \& H., R. R. 2007. Phylogenetic Evidence for a Flower Size and Number Trade-Off. American Journal of Botany, 94, 2059-2062.

Schmid, B. \& Harper, J. L. 1985. Clonal Growth in Grassland Perennials: I. Density and Pattern-Dependent Competition Between Plants with Different Growth Forms. Journal of Ecology, 73, 793-808.

Simmons, M., Bertelson, M., Windhager, S. \& Zafian, H. 2011. The performance of native and non-native turfgrass monocultures and native grass polycultures: An ecological approach to sustainable lawns. Ecological Engineering, 37, 1095-1103.

Slater, E. 2007. The Front Lawn as a work of art and nature in the age of chemical reproduction. Annual Meeting of the American Sociological Association 2007. New York.

Smith, L. S. \& Fellowes, M. D. E. 2013. Towards a lawn without grass: the journey of the imperfect lawn and its analogues. Studies in the History of Gardens and Designed Landscapes, 33, 1-13.

Smith, L. S. \& Fellowes, M. D. E. 2014a. The grass-free lawn: management and species choice for optimum ground cover and plant diversity. Urban Forestry \& Urban Greening., 13, 433-442

Smith, L. S. \& Fellowes, M. D. E. 2014b. The influence of species number on productivity, ground coverage and floral performance in grass-free lawns. Landscape and Ecological Engineering. , DOI: 10.1007/s11355-014-0264-9.

Steinberg, T. 2007. American green: The Obsessive Quest for the Perfect Lawn, New York, NY, W.W. Norton \& Co. 
699

700

701

702

703

704

705

706

707

708

709

710

711

712

Stewart, G. H., Ignatieva, M. E., Meurk, C. D., Buckley, H., Horne, B. \& Braddick, T. 2009. URban Biotopes of Aotearoa New Zealand (URBANZ) (I):Composition and diversity of temperate urban lawns in Christchurch. Urban Ecosystems., 12, 233-248.

Thomas, A. 2010. Royal Society for the Protection of Birds. Gardening for Wildlife. A complete guide to nature-friendly gardening., London, A\&C Black.

Thompson, K., Hodgeson, J. G., Smith, R. N., Warren, P. H. \& Gaston, K. J. 2004. Urban domestic gardens (III):Composition and diversity of lawn floras. Journal of Vegetation Science, 15, 371-376.

Wade, A. 2012. Greenacres: Landscaping with Native Plants. Prarie Maintenance. Wild Ones Handbook.: US Environmental Protection Agency.

Wagner, R. E. 1952 Effects of differential clipping on growth and development of seedling grasses and legumes. Journal of Agronomy and Crop Science., 44, 578-584. 